Témoigner Témoigner. Entre histoire et mémoire

Getuigen Revue pluridisciplinaire de la Fondation Auschwitz

$122 \mid 2016$

Révisionisme et négationisme

\title{
When the body is forgotten: The physical consequences of genocide for the survivors
}

Rwanda, episode 6

Quand le corps est oublié. Les séquelles physiques du génocide pour les rescapés.

Rwanda, épisode 6

\section{Rémi Korman}

Translator. Jennie Malcolm

\section{(2) OpenEdition}

\section{Journals}

Electronic version

URL: https://journals.openedition.org/temoigner/4678

DOI: 10.4000/temoigner.4678

ISSN: 2506-6390

Publisher:

Éditions du Centre d'études et de documentation Mémoire d'Auschwitz, Éditions Kimé

Printed version

Date of publication: 2 May 2016

Number of pages: 150-153

ISSN: 2037-4183

Electronic reference

Rémi Korman, "When the body is forgotten: The physical consequences of genocide for the survivors", Témoigner. Entre histoire et mémoire [Online], 122 | 2016, Online since 30 September 2021, connection on 04 January 2022. URL: http://journals.openedition.org/temoigner/4678; DOI: https://doi.org/ 10.4000/temoigner.4678 


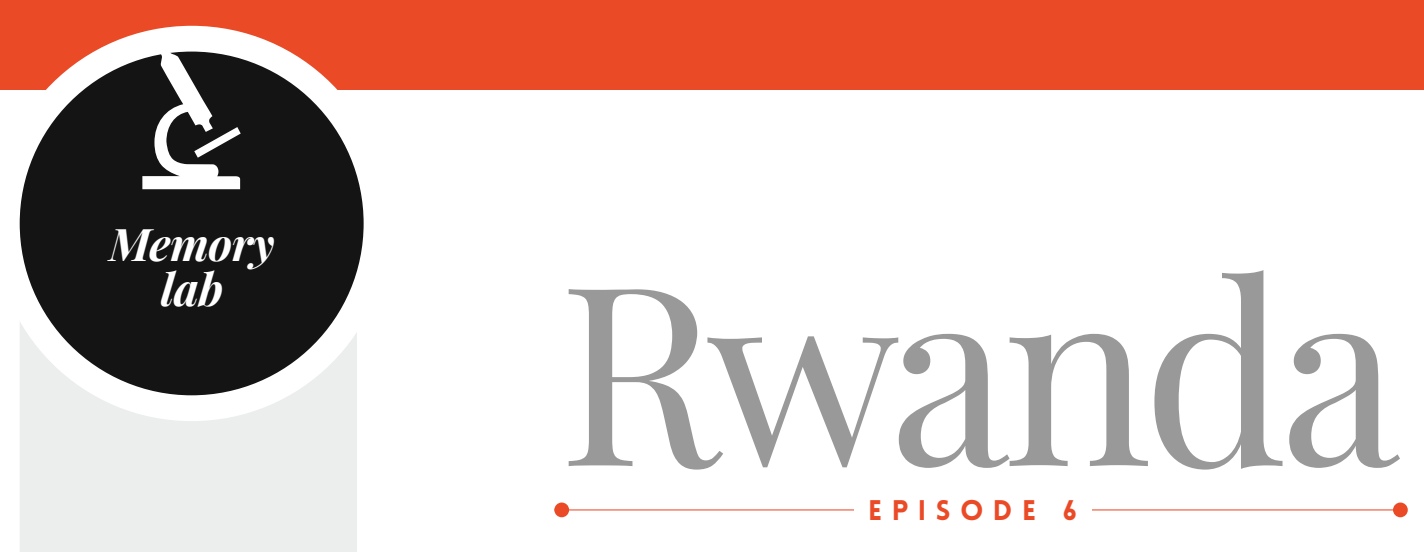

$\rightarrow$ This section aims at providing insight into processes of memory construction in different parts of the world. Instead of focusing on the events themselves, the Memory Laboratory explores collective ways of remembering, with a view to uncovering possible challenges, and sociopolitical consequences of memory work.

\section{WHEN THE BODY IS FORGOTTEN: THE PHYSICAL CONSEQUENCES OF GENOCIDE FOR THE SURVIVORS}

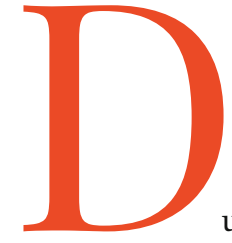

2015 , death struck two young survi vors of the genocide against the Tutsi living in diaspora, Berthe Kayitesi and Leander Rugali Murara. Berthe Kayitesi was 36 years old when she died of an aneurysm on 23 June 2015. She lived in Canada and had completed her university studies and recently defended her doctoral thesis (Kayitesi 2014). She was particularly known for her community involvement and had published a book on the role of child-headed households in Rwanda after the genocide (Kayitesi 2009). Leander Rugali Murara lived in Switzerland since the early 2000 s and worked for the Foyer-Handicap Foundation. He died aged 35 on 7 July 2015 by drowning, after suffering an epileptic seizure.

If the death of Berthe Kayitesi appears as natural, as heartbreaking as it is for a young woman of 36 to pass away, it is not the same for Leander Rugali Murara. For many survivors, his drowning is one of the consequences of genocide, as after 1994 he developed epilepsy due to the numerous beatings that were inflicted on him.

In this article, I wish to offer a short reflection on a largely neglected subject: the physical consequences of the genocide and the likely excess mortality of survivors after 1994.

\section{"THE EMPIRE OF TRAUMA"}

In a landmark work originally published in French in 2007, Didier Fassin and Richard Rechtman question the place given to the issue of trauma and the development of this concept in the past decades. The title of the book, The Empire of Trauma, is chosen to question the sometimes disproportionate place 


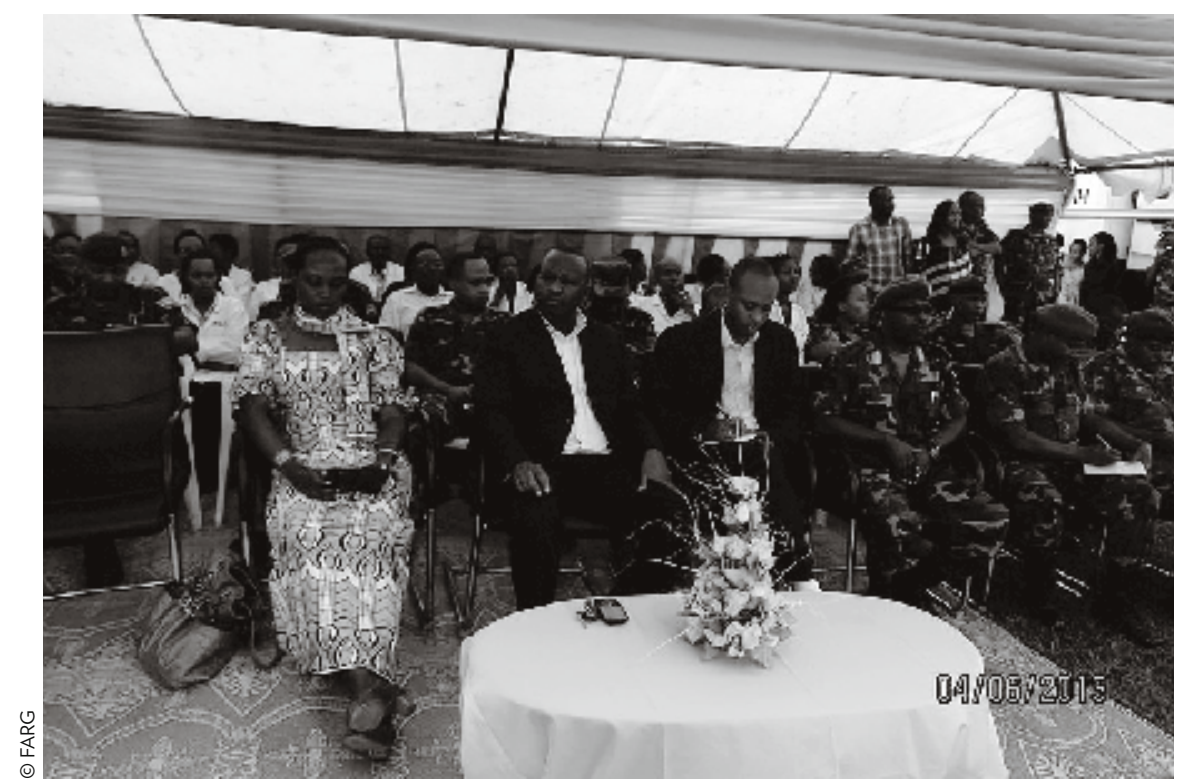

the issue of "trauma" is given after any event or crisis. In Rwanda, genocide has obviously led to numerous psychological consequences, especially for the survivors, and there exist special forms of genocidal trauma (Gishoma 2014). We note that the scientific literature on these issues is extremely abundant, covering dozens of $\mathrm{PhDs}$ and books, and hundreds of student dissertations and NGO reports.

Despite the generous attention to trauma in the scientific field, there is a clear lack of interest in the physical consequences of the genocide. This is all the more surprising as current historical research in fact largely focuses on types of violence against victims' bodies during the genocide (Audoin-Rouzeau $\&$ Dumas 2014). In the absence of a thorough analysis, several preparatory questions can be asked: do genocides generate a specific type of pathologies? How have the physical effects of the Rwandan genocide been treated since 1994? Which challenges do we face today?

Generally, since 1994, reports on groups of victims. First of all orphans (imfubyi) and widows (abapfakazi), then traumatized (abahungabanye) and finally disabled (abamugaye). If the first three groups have been widely researched, this is not the case of the last. There are few accurate statistics on this point. Since 1994, several genocide survivors' censuses were conducted. The first was carried out in 1998 by the MIJESCAFOP (Ministry of Youth, Sports, Culture and Vocational Training), the second in 2008 by MINALOC (Ministry of Local Government, Good Governance and Social Affairs) and $\ldots \bullet$ genocide survivors mention four major
- Medical Army Week for Genocide Survivors, 2013. 
- the National Institute of Statistics of Rwanda. These surveys are designed to count the number of survivors living in Rwanda, but also to enquire about their physical and medical living conditions. Because of methodological problems surrounding the reports, however, we do not possess reliable data. It is therefore difficult to know whether survivors indeed suffer from excess mortality compared to the general population, and what their specific needs are.

Disabled people or, using the vocabulary of the First World War, the "gueules cassées" of the genocide, become invisible, not only in the statistics but also in the public sphere. Révérien Rurangwa's testimony, which gives prominence to the physical consequences of the genocide, is in this regard an exception (Rurangwa 2006).

\section{SLOW MEDICAL CARE FOR SURVIVORS}

The trauma of genocide survivors has been looked after, for example, through the creation in 1995 of the CNT, the National Trauma Centre based in
Kigali. Yet are the physical scars of the genocide being properly treated?

Let us first recall that the death of a large part of the medical staff has led to a malfunction of the post-genocide health system. We know that a significant number of NGOs attended to the care of the survivors in the 1990s, as was the case for Révérien Rurangwa. Ibuka, an association of genocide survivors, also participated in identifying those people needing care, and disseminated information to FARG, the Relief Fund for Genocide Survivors, from its inception in 1998. FARG, whose budget represents $5 \%$ of the annual budget of the Rwandan state, has unfortunately experienced many failures, which regularly hampered access to decent health care for victims.

Because of the mismanagement of funds and accumulated debts, the issue of health was neglected for several years, as opposed to housing issues or tuition. Haggai Shyaka Mugabe noted that from 1998 to 2005 only 107 survivors were transferred abroad for
_ From right to left: Lt Col Dr Furaha, Dr Peter Adamson and Dr Ifepo Sofola talking to the media at Rwanda Military Hospital, 2014.

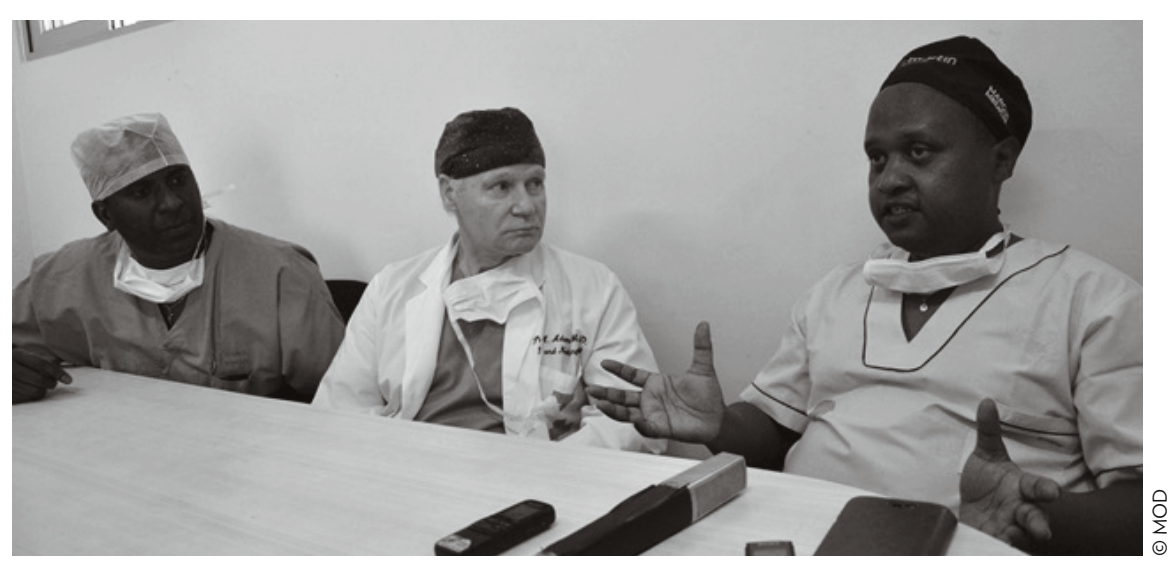


medical reasons (Shyaka 2009, 153). In fact, during the fifteen years following the genocide, many survivors were not treated, despite significant after-effects. The most dramatic case is probably that of the women raped and infected with AIDS. Many died of the consequences of their illness after the genocide and were abandoned a second time by the international community.

However, since 2010, significant medical treatment projects have been set up, as well as reconstructive surgery for survivors. In 2012 the Rwandan army (RDF or Rwandan Defence Forces) organized Medical Army Week for Genocide Survivors for the first time. The initiative was launched together with the FARG and aims to treat survivors in each district. In parallel, the Kanombe military hospital in Kigali was opened in 2012, specializing in plastic and reconstructive surgery. At present, there is only one specialist in plastic surgery in Rwanda,Lt. Charles Furaha, but the field is expanding (Deutsche Welle 2013).

There have been some positive developments in the Rwandan health system recently, such as the creation of a general health insurance, which leaves hope for a greater acknowledgement of genocide survivors' health issues. However, it is necessary that the physical scars of the genocide become a topic of intellectual, and obviously also a medical analysis. Rwanda may have rebuilt itself as a country, the genocide has left scars that are not only mental but physical as well.

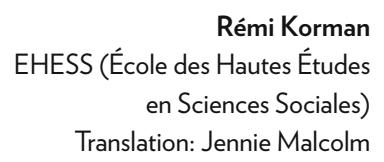

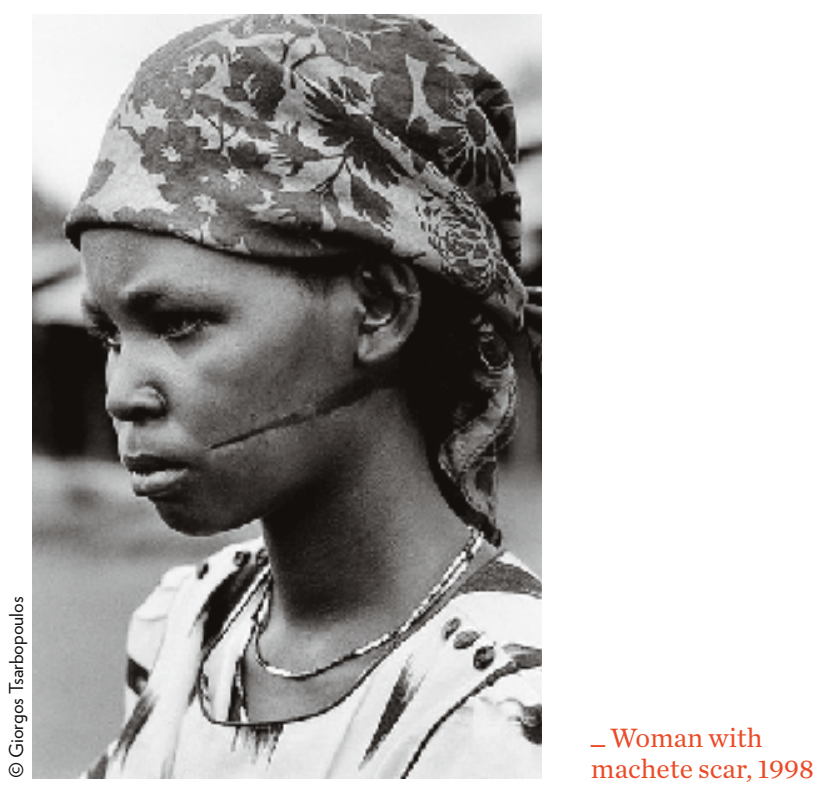

\section{WORKS CITED}

- Audoin-Rouzeau, Stéphane \& Hélène Dumas, 'Le génocide des Tutsi rwandais vingt ans après', Vingtième Siècle. Revue d'histoire 122(2), 2014, 3-16.

- 'Chirurgie réparatrice pour les séquelles du génocide', Magazine Santé on Deutsche Welle, 9 January 2013, www.ardmediathek.de (accessed 8 December 2015).

- Fassin, Didier \& Richard Rechman, The Empire of Trauma: An Inquiry into the Condition of Victimhood [2007], translated from the French by Rachel Gomme, Princeton University Press, 2009.

- Gishoma, Darius, Crises traumatiques collectives d'ihahamuka lors des commémorations du génocide des Tutsi: aspects cliniques et perspectives thérapeutiques, Louvain la Neuve, 2014.

- Kayitesi, Berthe, Demain ma vie. Enfants chefs de famille dans le Rwanda d'après, Paris: Laurence Teper, 2009.

- Kayitesi, Berthe, Conséquences et résilience liées à l'apprentissage et à la recherche sur le génocide des Tutsis: Cas des étudiants et des professeurs, Université d'Ottawa, 2014.

- Rurangwa, Révérien, Génocidé, Paris: Presse de la Renaissance, 2006.

- Shyaka Mugabe, Aggée, Réparation et réconciliation au Rwanda: portée et limites de la justice transitionnelle, Université Catholique de Louvain la Neuve, 2009. 